\title{
A Critical Analysis of Concepts Associated with Sustainability in Early Childhood Curriculum Frameworks Across Five National Contexts
}

\author{
Kassahun Weldemariam ${ }^{1}$ (D) Diane Boyd ${ }^{2}$. \\ Nicky Hirst ${ }^{2}$ - Barbara Maria Sageidet ${ }^{3}$. \\ Jamison K. Browder ${ }^{4}$ Leanne Grogan ${ }^{5}$. \\ Fran Hughes,
}

Published online: 14 September 2017

(C) The Author(s) 2017. This article is an open access publication

\begin{abstract}
Curriculum frameworks have an important role in providing guidance to early childhood practitioners on how to integrate knowledge about sustainability into their practice. This article examines how ideas about sustainability are integrated in the early childhood curricula for Australia, England, Norway, Sweden and the USA. The analyses were guided by critical inquiry and a cross-national dialogue and focused on four aspects of the curricula: sustainability presence, views of the child, human-environment relationship and philosophical/theoretical underpinnings on ideas expressed about sustainability. Ideas about sustainability were more implicitly present than explicitly stated in most curricula. It was not evident that
\end{abstract}

Kassahun Weldemariam

kassahun.weldemariam@gu.se

Diane Boyd

d.j.boyd@1jmu.ac.uk

Nicky Hirst

n.j.hirst@ljmu.ac.uk

Barbara Maria Sageidet

barbara.sageidet@uis.no

Jamison K. Browder

jkbrowder@hotmail.com

Leanne Grogan

l.grogan@latrobe.edu.au

Fran Hughes

fran.hughes@tafensw.edu.au

1 Department of Pedagogical, Curricular and Professional Studies, Faculty of Education, University of Gothenburg, Läroverksgatan 15, 40530 Gothenburg, Sweden

2 School of Education, Liverpool John Moores University, Barkhill Road, Liverpool, UK

3 Department of Early Childhood Education, Faculty of Arts and Education, University of Stavanger, Hagbart Line huset, 4036 Stavanger, Norway 
children were viewed as world citizens with agency to help foster sustainability. With respect to human-environmental relationship, the framework from Australia expressed greater reciprocity and entanglement, while other frameworks were more anthropocentric despite the variation among curricula. All five frameworks embodied a sociocultural, human development approach with respect to the philosophical and theoretical underpinnings. There is a need to consider alternative frameworks that offer broader and more inclusive worldviews about sustainability that includes embracing human, non-human and other species within an assemblage of common worlds.

Keywords Anthropocentric · Curriculum theory · Early childhood education · Sustainability · Education for sustainability · Child agency

Résumé Les programmes d'études jouent un rôle important dans l'orientation des praticiens de la petite enfance sur la manière d'intégrer les connaissances sur la durabilité dans leur pratique. Cet article examine comment les idées sur la durabilité sont intégrées dans les programmes préscolaires en Australie, Angleterre, Norvège, Suède et aux États-Unis. Les analyses ont été guidées par une enquête critique et un dialogue transnational, et axées sur quatre aspects des programmes: la présence de la durabilité, les perspectives de l'enfant, les relations entre l'humain et l'environnement et les fondements philosophiques/théoriques soutenant les idées exprimées sur la durabilité. Les idées sur la durabilité sont plus implicitement présentes qu'explicitement énoncées dans la plupart des programmes. Il n'est pas évident que les enfants sont considérés comme des citoyens du monde ayant la capacité d'agir pour favoriser la durabilité. En ce qui concerne les relations entre l'humain et l'environnement, le programme de l'Australie exprime plus de réciprocité et d'interrelation tandis que les autres sont plus anthropocentriques. Les cinq programmes incluent tous une approche socioculturelle du développement humain comme fondements philosophiques et théoriques. Il est nécessaire d'envisager des programmes alternatifs qui offrent des visions du monde plus larges et plus inclusives sur la durabilité, et qui comprennent l'inclusion des espèces humaine, non humaines et autres à l'intérieur d'un ensemble de mondes communs.

Resumen Los marcos curriculares tienen un papel importante en la provisión de orientación a los profesionales de la primera infancia sobre cómo integrar el conocimiento sobre la sostenibilidad en su práctica. Este artículo examina cómo las ideas sobre sostenibilidad se integran en los planes de estudio de la primera infancia para Australia, Inglaterra, Noruega, Suecia y los Estados Unidos. Los análisis fueron

4 College of Education, University of South Carolina, 820 Main Street, Columbia, SC 29208, USA

5 School of Education, Outdoor and Environmental Studies, La Trobe University, Edwards Road, P.O. Box 199, Bendigo, VIC 3552, Australia

6 School of Education, University of New England, Armidale, Australia

7 TAFE NSW, Cnr Darley Road and King Street, Randwick, NSW, Australia 
guiados por una investigación crítica y un diálogo transnacional y se centraron en cuatro aspectos de los currículos: presencia de sostenibilidad, puntos de vista del niño, relación hombre-ambiente y fundamentos filosóficos/teóricos de las ideas expresadas sobre sostenibilidad. Las ideas sobre la sostenibilidad estaban más implícitamente presentes que las que se indicaban explícitamente en la mayoría de los planes de estudio. No era evidente que los niños fueran vistos como ciudadanos del mundo con la agencia para ayudar a fomentar la sostenibilidad. Con respecto a la relación humano-ambiental, el marco de Australia expresó mayor reciprocidad y enredo, mientras que otros marcos eran más antropocéntricos. Los cinco marcos incorporaron un enfoque sociocultural, de desarrollo humano con respecto a los fundamentos filosóficos y teóricos. Hay una necesidad de considerar los marcos alternativos que ofrecen visiones de mundo más amplias y más inclusivas sobre la sostenibilidad, que incluye abrazar a las especies humanas, no humanas y otras, dentro de un conjunto de mundos comunes.

\section{Introduction}

Although there is no agreed definition on what sustainability is, it can broadly be described as a discipline that requires major efforts to ensure the well-being of people and planet now and the future. Education for sustainable development (ESD) refers to reorienting educational practices towards the same end (UNESCO 2005). Since sustainability has increasingly been flagged as an important issue within early childhood education, it is opportune to investigate the ways in which sustainability is conceptualised in current early education curricular documents. The purpose of this article is to compare five national early childhood curricula (Australia, England, Norway, Sweden and USA) with respect to four characteristics of the curricula that reflect sustainability concepts: (1) presence of sustainability; (2) views of the child; (3) human-environment relationships; and (4) philosophical and theoretical underpinnings. These four characteristics emerged from a cross-cultural dialogue among the authors who come from different, albeit mainly "Western", parts of the world but who share a concern about the future of the Earth and a belief that children are critical for creating a more sustainable world now and in the future.

The relevance of sustainability to early childhood education and the need to engage young children with a sustainability ethos early in life has been well documented (Centre for Environment and Sustainability 2009; Davis 2009; Davis and Elliott 2014; Pramling Samuelsson and Kaga 2008). This literature has contributed to an increased focus on sustainability within early childhood pedagogy, curriculum and research which, in turn, led to the emergence of the early childhood education for sustainability (ECEfS) field. Over the past decade, ECEfS discourses have evolved over time, and also have returned over time, to include nature conservation education, nature study and environmental education; relationship with nature; environmental stewardship; education about and for the environment; teachers' understanding and implementation of sustainability practices; and children's rights and the contemporary notion of children as change agents and 
critical thinkers (Barratt Hacking et al. 2007; Davis 2009; Davis and Elliott 2014; Hedefalk et al. 2014; Somerville and Williams 2015).

Although there is substantial conceptual and policy-related research, there is less research on how sustainability is actually represented in curricula. This paper contributes to such curriculum research with a focus on the early childhood curriculum in five "Western" countries and located on three different continents: Australia, England, Norway, Sweden and USA. This selection was pragmatic since the authors are, in one way or another, connected to one of these countries and are familiar with both early childhood education and ESD. The curricula of interest are briefly described below.

\section{Australia}

The Early Years Learning Framework is an outcomes-based curriculum framework (EYLF) that forms part of Australia's National Quality Framework which encapsulates the legislation, regulations, quality standards and approved curriculum frameworks for all early childhood provisions in Australia (DEEWR 2009). While the EYLF is the national curriculum framework, some Australian states may choose to use their own curriculum if it has been approved by the Australian Children's Education and Care Quality Authority (ACECQA) which manages accreditation processes and registration of early childhood services. The aim of the curriculum is to "extend and enrich children's play based learning from birth to 5 years and through the transition to school" (DEEWR 2009, p. 5).

\section{England}

The newly revised Early Years Foundation Stage (DfE 2017) is a mandatory framework for all early years providers in England. The framework sets the standards that all early years providers must meet. It outlines learning outcomes and developmental goals and highlights the promotion of children's "school readiness" through its teaching and learning approaches to provide a strong foundation "for good future progress through school and life" (p. 5).

\section{Norway}

The newly revised Norwegian National Curriculum for kindergartens (Ministry of Education and Research 2017) is a regulatory framework, established by law, governing the purpose, fundamental values, content and tasks of kindergartens. It also gives basic guidelines for activities with the children. The new curriculum is implemented from August 2017 (Ministry of Education and Research 2017).

\section{Sweden}

The Swedish National Curriculum for the Preschool (Lpfö 1998, 2016) is a regulatory national curriculum that formulates fundamental values, directive learning goals and content together with specific responsibilities for staff and the 
head of the preschool. Without being prescriptive, the curriculum highlights general goals that each centre should strive to achieve. Documentation, evaluation and development of the quality of the preschool are also stated without dictating in what specific ways these practices should be done (Skolverket 2016). Sweden is currently undergoing a curriculum review, and a revised version is expected to be enacted from autumn of 2018 .

\section{USA}

In the USA, the Head Start Early Learning Outcomes Framework (Office of Head Start 2015) is not a mandated or compulsory framework. However, it has been widely used to inform curricula. It describes how children progress across key areas of learning and development and specifies learning outcomes in these areas. The intent of the document is to support early childhood professionals' understanding of how to provide meaningful, appropriate learning opportunities to children and engage families in the learning process (p. 2).

\section{Significance of the Current Study}

Only a few studies have specifically and exclusively examined how sustainability has been integrated and addressed in early years' curricula. A study by ÄrlemalmHagsér and Davis (2014) compared Sweden and Australia's early years national curricula in the light of four curricular aspects: inclusion of concepts of sustainability; recognition of human place in nature and environmental stewardship; critical thinking for sustainability; and reference to children as active agents and citizens participating for change. A central finding was that the two curricular documents did not portray children as active and agentic citizens who were able to participate and express their voices on public and global issues such as sustainability.

The study by Ärlemalm-Hagser and Davis' (2014) forms the basis for this paper as it provided a template for organising and analysing the selected curricula. Using Ärlemalm-Hagser and Davis' article as a spring board, this study takes a different path and provides more depth of analysis. For instance, while the previous study was mainly focused on the explicit inclusion of sustainability concepts, our interest is to elicit and pinpoint both the explicit and implicitly embedded concepts. Likewise, Ärlemalm-Hagser and Davis considered the extent to which human's place in nature and environmental stewardship is recognised, while our focus is on the curricular manifestations of human-environment/nature-culture entanglement. We focus on "entanglement" as it comes from a critical stance towards anthropocentrism which also problematises and challenges the notion of stewardship (Taylor 2017).

The notion of entanglement calls for an ontological prerequisite in which human and the environment are inevitably intertwined and cannot be viewed separately (Barad 2007; Taylor 2013). Based on Ärlemalm-Hagser and Davis' work, this study seeks to broaden the scope with different perspectives to help move sustainability in early childhood education beyond anthropocentrism by adding some new aspects of 
analyses (theoretical underpinnings and the human-environment entanglement) and modifying those previously addressed by Ärlemalm-Hagser and Davis (2014).

\section{Methodology}

The methodology in this study is a content analysis based on collaborative inquiry. The investigation was undertaken by members of an international network of early childhood education researchers, Transnational Dialogues (TND) in ECEfS research. It was anticipated that such an international collaboration would "demystify and democratize the process of constructing knowledge" (Bray et al. 2000, p. 19). This collaboration emerged from a TND meeting in June 2015 at Stavanger University, Norway, to discuss emerging issues surrounding ECEfS. A research theme that developed during the meetings focused on the presence of sustainability within early years' curricula frameworks. After the meeting, the TND participants continued to explore and broaden this theme by collecting data within a table using a collaborative file-hosting service (Drop Box). The table and the ensuing bodies of text were scripted through an online word processor (Google docs). This community of practice (Lave and Wenger 1991) was further enhanced by face-to-face meetings in Boston, USA, in September 2016.

The primary investigation of the early years' curricula was conducted by each author-researcher from their home country, drawing on local knowledge and experience, thus enhancing the grounding of the investigation. In addition, the researchers shared the "coding frame" (Silverman 2011, p. 65) during the data collection and analysis processes through completion of an evolving "running" table with the commonly identified four curricular aspects of sustainability. An inductive thematic analysis was employed during the research process (Guest et al. 2012) focused on the four coding themes identified. As the process developed, the interplay between individual and group reflection was conducted through dialogues (Bray et al. 2000) which sometimes led to a rethinking of our own knowledge and understanding of our "home" curriculum frameworks. In structuring our analytical framework, adopted from Ärlemalm-Hagser and Davis (2014), the four aspects of the curriculum discussed are described below.

\section{Theme 1: Presence of Sustainability}

In order to insure teachers' implementation of sustainability, Elliott and McCrea (2015) pointed out the need to demystify sustainability within curriculum policy. The focus aspect was to trace languages addressing sustainability either explicitly or implicitly. The authors believed that proper manifestation and implementation of sustainability in the early years settings required it to be stated in an explicit and straightforward manner. However, if this was not the case, the authors sought implicit languages/indirect representations of sustainability.

We focused on the commonly used, but increasingly challenged, pillars of sustainability: environment, social-cultural and economic aspects while bearing in mind the intertwined nature and a holistic view of sustainability. Explicit language 
refers to the literal usage of the word "sustainability", while implicit language refers to the use of indirect/associated concepts (e.g. environmental education, nature-based education, ecological approach, biodiversity, social diversity, solidarity, saving, reusing, recycling).

\section{Theme 2: View of the Child}

The notion of children as change agents with the capacity to actively participate in complex matters (such as sustainability) has been well documented in ECEfS research (Davis and Elliott 2014; Davis 2015) and in the sociology of childhood studies (Vandenbroeck and Bie 2006). Our interest on this aspect is due to the intricately intertwined nature of sustainability challenges in children's lives. Growing up in the Anthropocene and anticipated to have a longer time to live than adults, today's young children are and will be disproportionately affected by human beings' unsustainable lifestyles (Corcoran and Osano 2009). As indicated by Malone (2004), children have a special interest in sustainability since they are the current and future contributors and decision-makers.

This scenario positions the child among the major actors and stakeholders in the endeavour towards a sustainable society. Hence, ensuring the recognition of children as active change agents within curriculum and policy documents is an inevitable aspect in the endeavour towards engaging children with sustainability issues. Here, our investigation focuses on curriculum "utterances" referring to the child. However, we are not solely focusing on the agency of the human child; rather we are also attentive to the agency of the more-than-human world and the intricate relationality between the two.

\section{Theme 3: Human-Environment Relationships}

The interconnection between human and the physical environment or "nature" and culture is a discussion that has endured as a topic for debate within sustainability and environmental education. As many people have described this, predominantly in the Western context, nature and culture have often been considered as separate and distinct entities (Haraway 2008). Haraway problematises the divergence of modern culture from "nature" and introduced the term "nature-culture" as a way of signifying the inseparability and entanglement of the natural and the cultural against the ontological split assumed in many modern traditions. Our interest in this aspect is to look for and examine curriculum "utterances" referring to human-environment/nature-culture relationships which are a less discussed area within ECEfS. In an effort to learn how children are viewed and taught about their relationship with the environment, we draw on this aspect and critically examine how the curricular documents represent/construct the environment around the child and children's interconnections with it.

\section{Theme 4: Philosophical and Theoretical Underpinnings}

Although none of the five curricula explicitly spelled out its underpinning theory or philosophy, these were inter-subjectively interpreted by drawing on our own 
familiarity and work experience with the frameworks and by reaching agreement within the author team. Theories and philosophical assumptions are critical as they are decisive in determining the worldview, the values and the ontological and the epistemological underpinnings embedded in curriculum. This has a direct influence on how children are prepared to engage with contingent issues (such as sustainability) in today's precarious times. Scholars such as Gibson et al. (2015) and Malone et al. (2017) argue that humans need to know more and know differently which has brought about the necessity to reimagine our view on learning for sustainability and how the very notion of sustainability itself is constructed.

Through the exploration of the theories and philosophies behind each curriculum, the authors hope for alternative understandings of ontological and epistemological underpinnings to emerge. Moreover, the relatively open, less structured characteristics of early childhood curricula would allow such rethinking and reimagining which might lead us to alternative ontologies. Hence, it was with this intention of exploring alternative ways of being and knowing that we sought to investigate the theoretical and philosophical basis of the five frameworks.

\section{Theoretical Framework and Analytical Approach}

As a theoretical framework, critical inquiry and post-humanism perspectives are employed. Critical inquiry is used as it allowed the opportunity to engage in relevant and context-related, critical thinking.

The authors followed the main stages of critical inquiry: reading the curricula, reconstructing the main arguments related to sustainability and responding to the claims (Boylan 2009). Critical inquiry is a dialectical process involving the comparative weighing of a variety of positions and arguments, while argumentation is seen as a way of arriving at reasoned judgements on complex issues (Battersby and Bailin 2011). Six aspects of critical inquiry described by Battersby and Bailin are relevant here. First, the dialectical context, and the current and historical debate around an issue to be able to appreciate the depth of the insights involved in the issue. Second, an understanding of the current state of practice and of the beliefs surrounding an issue. This may reveal what is significant or contentious about an issue. Third, an understanding of the intellectual, political, historical and social contexts in which an issue is embedded can help us in understanding and interpreting arguments and can reveal assumptions, underlying arguments and positions. Fourth, the knowledge of the relevant disciplinary context. Fifth, information about the sources of an argument, and finally, awareness of one's own beliefs and biases. Adopting these procedures, the authors examined and compared concepts associated with sustainability as embedded in the contents of the curricula.

Coupled with critical inquiry, post-humanism and its critique on anthropocentric humanism has been used. Post-human concepts such as entanglement, assemblage, common world, shared and distributed/relational agency (Barad 2007; Latour 2005; Taylor 2013, 2017) are adopted in order to challenge the dominant sociocultural, child-centric and cognitive-based learning. Post-humanism challenges child-centred developmental environmental pedagogies and calls for pedagogies that bring 
attention to children's entanglements within multiple human and more-than-human relations (Taylor 2013, 2017).

While analysing the curricula contents and features, we used the following procedure. First each author began by thoroughly scrutinising his or her country's curriculum. This was followed by successive discussion among the author team which resulted in the identification of the four curricular aspects on which to focus and guide the comparative analysis. Once the aspects were identified, each author re-examined his or her respective curriculum contents in the light of the four aspects and shared the results with other authors followed by collaboration to compile the whole body of the article. For a meaningful exemplification and elucidation of curricular characteristics, various excerpts are quoted in the findings section.

\section{Findings}

An overview of the findings is presented in Table 1 followed by discussion of each analytic aspect.

\section{Presence of Sustainability}

We have learnt that there are differences in the visibility of the term, sustainability, across the documents despite the presence of some common characteristics. As indicated in Table 1, there were very few explicit references to sustainability in some of the curricula; therefore, the authors sought to locate the implicit indicators of sustainability. Australia and Norway are the two countries addressing sustainability in a more explicit manner. The new Norwegian curriculum has stated that "the kindergarten has to promote democracy, diversity, mutual respect, equality, sustainable development, life skills and health" (p. 7) and it also states "The kindergarten has an important task to promote values, attitudes and practices for more sustainable societies .... the kindergarten shall contribute to give children an understanding that [any] actions have consequences in future" (Ministry of Education and Research 2017, pp. 10-11).

Likewise, the Australian curriculum states: "the service takes an active role in caring for its environment and contributes to a sustainable future... sustainable practices are embedded in service operations... educators play role to facilitate and embed sustainability in all routines and practices" (DEEWR 2009, p. 74).

Although the Swedish curriculum does not explicitly highlight sustainability, there were some similarities with Norwegian curriculum which resonates with earlier findings (Alvestad and Samuelsson 1999). Both curricula share common features of a strong nature-oriented outdoor education tradition and an ecological approach, which evolved from the 1960s in connection with the public awareness of indigenous people's (Sami) culture (Sageidet 2014). Australia also recognises the potential of the culture of its Aboriginal indigenous people and indicates that indigenous perspectives can promote understanding of the interconnectedness of nature and culture (DEEWR 2009). 
Table 1 An overview of findings on the four content themes explored in the five national curricula

\begin{tabular}{|c|c|c|c|c|}
\hline \multirow{2}{*}{$\begin{array}{l}\text { Country, } \\
\text { curriculum title } \\
\text { and promulgated } \\
\text { year }\end{array}$} & \multicolumn{4}{|l|}{ Curricular aspects } \\
\hline & $\begin{array}{l}\text { Sustainability } \\
\text { presence }\end{array}$ & View on the child & $\begin{array}{l}\text { Human- } \\
\text { environment } \\
\text { relationship }\end{array}$ & $\begin{array}{l}\text { Philosophical/ } \\
\text { theoretical } \\
\text { underpinning }\end{array}$ \\
\hline $\begin{array}{l}\text { Australia Belonging } \\
\text { Being and } \\
\text { Becoming } \\
\text { (DEEWR 2009) }\end{array}$ & $\begin{array}{l}\text { Explicit: embedded } \\
\text { in daily routines } \\
\text { and practices; } \\
\text { environmental } \\
\text { responsiveness; } \\
\text { connection to the } \\
\text { natural world; } \\
\text { environmental } \\
\text { responsibility, } \\
\text { care/respect for } \\
\text { environment and } \\
\text { contribution to a } \\
\text { sustainable future. } \\
\text { Yet, conceptually } \\
\text { vague and } \\
\text { implementation is } \\
\text { unclear }\end{array}$ & $\begin{array}{l}\text { Active learners; } \\
\text { critical thinkers } \\
\text { and problem } \\
\text { solvers but not } \\
\text { applied directly to } \\
\text { sustainability } \\
\text { issues; agency } \\
\text { confined to } \\
\text { children's social } \\
\text { world; seen as } \\
\text { needing to develop } \\
\text { skills to be active } \\
\text { future citizens; } \\
\text { have rights; sense } \\
\text { of belonging to } \\
\text { groups and } \\
\text { communities }\end{array}$ & $\begin{array}{l}\text { Interconnection } \\
\text { between human, } \\
\text { other species and } \\
\text { the physical world, } \\
\text { and hence care, } \\
\text { respect and } \\
\text { appreciation for } \\
\text { natural } \\
\text { environment }\end{array}$ & $\begin{array}{l}\text { Predominantly } \\
\text { sociocultural } \\
\text { theory }\end{array}$ \\
\hline $\begin{array}{l}\text { England Early Years } \\
\text { Foundation Stage } \\
\text { (DfE 2017). }\end{array}$ & $\begin{array}{l}\text { Not explicit. } \\
\text { Understanding the } \\
\text { world through } \\
\text { natural play: } \\
\text { physical } \\
\text { environment, } \\
\text { plants, and } \\
\text { animals. } \\
\text { Intergenerational } \\
\text { link through family } \\
\text { and community; } \\
\text { relationship and } \\
\text { sensitivity to } \\
\text { others; equal } \\
\text { opportunity }\end{array}$ & $\begin{array}{l}\text { The child is } \\
\text { "supported", must } \\
\text { "listen attentively" } \\
\text { "respond" and } \\
\text { "follow } \\
\text { instructions" }\end{array}$ & $\begin{array}{l}\text { Make sense of the } \\
\text { world: the physical } \\
\text { world/ } \\
\text { environmental } \\
\text { view }\end{array}$ & $\begin{array}{l}\text { Constructionist- } \\
\text { Piagetian with a } \\
\text { goal-orientated } \\
\text { philosophy. } \\
\text { Positive } \\
\text { relationships and } \\
\text { enabling } \\
\text { environments. } \\
\text { Sets standards to } \\
\text { promote "school } \\
\text { readiness" (EYFS, } \\
\text { DfE 2017: 5) }\end{array}$ \\
\hline $\begin{array}{l}\text { Norway National } \\
\text { Framework Plan } \\
\text { for the Content and } \\
\text { Tasks of } \\
\text { Kindergartens } \\
\text { (Ministry of } \\
\text { Education and } \\
\text { Research 2017) }\end{array}$ & $\begin{array}{l}\text { Explicit: one of the } \\
\text { basic values, initial } \\
\text { understanding of } \\
\text { sustainability; } \\
\text { respect and care for } \\
\text { nature; outdoor } \\
\text { activity, social } \\
\text { competence, } \\
\text { democracy, } \\
\text { equality, food } \\
\text { production, } \\
\text { consumption, } \\
\text { learning about the } \\
\text { UN and Rights of } \\
\text { the child: and } \\
\text { acknowledgement } \\
\text { of indigenous } \\
\text { (Sami) practices }\end{array}$ & $\begin{array}{l}\text { Unique individual } \\
\text { with own needs, } \\
\text { able to express } \\
\text { their views. Focus } \\
\text { on adult's role for } \\
\text { children's } \\
\text { democratic } \\
\text { participation }\end{array}$ & $\begin{array}{l}\text { Respect, love, care } \\
\text { for nature. Learn } \\
\text { about plants, } \\
\text { animals, } \\
\text { biodiversity and } \\
\text { natural } \\
\text { phenomena. } \\
\text { Understanding } \\
\text { interrelations in } \\
\text { nature and human- } \\
\text { nature relationship, } \\
\text { responsibility for } \\
\text { natural } \\
\text { environment in the } \\
\text { kindergarten's } \\
\text { everyday life }\end{array}$ & $\begin{array}{l}\text { Sociocultural } \\
\text { learning theories. } \\
\text { More process than } \\
\text { goal oriented. } \\
\text { Christian and } \\
\text { humanistic values, } \\
\text { learning through } \\
\text { everyday events } \\
\text { that occur in social } \\
\text { interaction, play } \\
\text { and structured } \\
\text { activities }\end{array}$ \\
\hline
\end{tabular}


Table 1 continued

\begin{tabular}{|c|c|c|c|c|}
\hline \multirow{2}{*}{$\begin{array}{l}\text { Country, } \\
\text { curriculum title } \\
\text { and promulgated } \\
\text { year }\end{array}$} & \multicolumn{4}{|l|}{ Curricular aspects } \\
\hline & $\begin{array}{l}\text { Sustainability } \\
\text { presence }\end{array}$ & View on the child & $\begin{array}{l}\text { Human- } \\
\text { environment } \\
\text { relationship }\end{array}$ & $\begin{array}{l}\text { Philosophical/ } \\
\text { theoretical } \\
\text { underpinning }\end{array}$ \\
\hline $\begin{array}{l}\text { Sweden Curriculum } \\
\text { for the Pre-School, } \\
\text { Lpfö } 98 \\
\text { (Skolverket 2016) }\end{array}$ & $\begin{array}{l}\text { Explicit in a } \\
\text { supporting } \\
\text { document, but not } \\
\text { quite explicit in the } \\
\text { curriculum. Strong } \\
\text { emphasis on } \\
\text { environmental } \\
\text { issues, nature- } \\
\text { based/outdoor } \\
\text { education. } \\
\text { Ecological } \\
\text { approach with } \\
\text { positive present } \\
\text { and future trust and } \\
\text { children as part of } \\
\text { the natural cycle. } \\
\text { Fundamental } \\
\text { values include: } \\
\text { democracy, } \\
\text { participation, } \\
\text { respect, equality, } \\
\text { justice, diversity, } \\
\text { empathy and world } \\
\text { citizenship }\end{array}$ & $\begin{array}{l}\text { Competent, active, } \\
\text { responsible, } \\
\text { agentic, able to } \\
\text { influence the } \\
\text { pedagogical } \\
\text { environment and } \\
\text { beyond. Can } \\
\text { influence everyday } \\
\text { routine, learning } \\
\text { and preschool } \\
\text { environment }\end{array}$ & $\begin{array}{l}\text { Children as part of } \\
\text { nature and its } \\
\text { cycle; how people, } \\
\text { nature and society } \\
\text { influence/connect } \\
\text { each other; } \\
\text { conservation and } \\
\text { caring attitude } \\
\text { towards nature }\end{array}$ & $\begin{array}{l}\text { Sociocultural; } \\
\text { experience } \\
\text { oriented; goal } \\
\text { oriented; activity/ } \\
\text { project approach }\end{array}$ \\
\hline $\begin{array}{l}\text { USA Head Start } \\
\text { Early Learning } \\
\text { Outcomes } \\
\text { Framework: Ages } \\
\text { Birth to Five } \\
\text { (HSELOF 2015). }\end{array}$ & $\begin{array}{l}\text { Not explicit. Themes } \\
\text { addressed include: } \\
\text { inclusive and } \\
\text { collaborative } \\
\text { approach, sense of } \\
\text { belonging to } \\
\text { family and } \\
\text { community, } \\
\text { reusing/recycling }\end{array}$ & $\begin{array}{l}\text { Every child is unique } \\
\text { and can succeed } \\
\text { with adults' help. } \\
\text { The child is not } \\
\text { viewed as active } \\
\text { citizen. The child is } \\
\text { influenced by the } \\
\text { environment. No } \\
\text { mentioning of } \\
\text { agency at all }\end{array}$ & $\begin{array}{l}\text { Experience in nature: } \\
\text { e.g. collecting } \\
\text { leaves and } \\
\text { pinecones in the } \\
\text { fall }\end{array}$ & $\begin{array}{l}\text { Constructivist- } \\
\text { Piaget's discrete } \\
\text { developmental } \\
\text { stages and } \\
\text { Vygotsky's } \\
\text { sociocultural } \\
\text { approach }\end{array}$ \\
\hline
\end{tabular}

Despite the absence of the term sustainability in the Swedish curriculum, its supporting government documents have highlighted it as follows: "A major challenge is to educate future generations to understand and act on the principle of sustainable development ... preschool is a natural starting point for this work because interests, values and skills are formed during the early years" (Swedish Ministry of Education and Research 2010, pp. 14-15). The upcoming new 2018 version of the Swedish curriculum will explicitly highlight global question and sustainability (Utbildningsdepartementet 2017).

Sustainability was not explicitly mentioned in the framework for the USA or England; hence, we will discuss the implicit connections to sustainability. We acknowledge the implicit references were derived from personal interpretations based on a "home" perspective, personal awareness of the topic, philosophy 
associated with early childhood education and discussion among co-authors. In most of the curricula, the visibility of environmental sustainability within the written language was more pronounced than social-cultural and economic aspects (Table 1). This may partially explain why practitioners tend to view sustainability only in terms of environmental or "green" issues (Hill et al. 2005).

The Australian, Norwegian and Swedish curricula acknowledge the importance of outdoor learning environments by having a mandatory requirement to connect children to their natural environment and to contribute to a sustainable future (Table 1). Yet, outdoor education is not adequately acknowledged in either the USA or the English curriculum. The English framework suggests a tacit reference to understanding the physical world and intergenerational relationships with people and communities, and reference to the outdoors has been reduced to daily access to the outdoors and making sense of the physical world (DfE 2017). In both England and the USA, there is, however, a growing international awareness of the value of the outdoors in the early years in promoting a more holistic development of children (Knight 2013; Schein 2014; Sobel 2015).

It was noted that democracy, freedom, rights, care for others, creating world citizens, empathy, responsibility and conflict management were fundamental values in the Swedish curriculum (Table 1). Likewise, the Norwegian framework is anchored in the fundamental values of respect, diversity, equity and solidarity (Table 1). Within the Australian framework, there is a focus on the rights of the child and his/her agency, with guiding principles reflecting respectful and reciprocal relationships, reflective practice, partnerships, equity and diversity (DEEWR 2009). The English framework has guiding principles designed to "shape" practice. These principles recognise the uniqueness of each child, emphasising positive relationships in enabling environments (DfE 2017). However, there is no reference to the voice of the child or explicit mention of democracy; rather, it employs language such as "equality of opportunity and anti-discriminatory practice" (DfE 2017, p. 5). The USA framework also makes no explicit reference to democracy. Instead it uses a language of "inclusion" and "collaboration" and "sense of identity and belonging with family and other community members" as features of good practice (Office of Head Start 2015, p. 3).

Examining the language of sustainability has allowed us to see the extent to which sustainability has been explicitly and implicitly embraced together with the beliefs and values embedded in the curriculum. We find that the absence of adequate coverage of sustainability concepts in these national frameworks could be a concern for meaningful engagement with sustainability in preschool settings.

\section{View of the Child}

There is well-documented research evidence on children's agency and their competence to take part in matters that concern them, in general, and their active engagement in sustainability, in particular (Berthelsen and Brownlee 2005; Smith

2007; Ärlemalm-Hagser and Davis 2014; Davis and Elliott 2014). However, there has not been enough research on how curriculum documents construct the role of children in relation to sustainability issues and the sustainability competence that 
children ought to obtain. The five curricula examined have portrayed different images of the child which may impact on children's participatory roles both locally and globally.

The Swedish curriculum identifies children's active and democratic influence when participating in planning their learning, preschool routine and the preschool environment at large (Table 1). Although children's agency in some cases appears to be limited at the individual and school level, the curriculum broadly portrayed children as world citizens who are encouraged to be active change agents for today's and the future world. The Australian curriculum also identifies children's agency and describes them as active learners who are able to influence their own learning (Table 1). However, the agency appeared to be confined to their social and relational world (immediate environment, individual life, family and preschool setting) rather than a broader role as an active citizen influencing broader environmental and global issues. Both findings resonate with an earlier comparative study (Ärlemalm-Hagser and Davis 2014) which identified the portrayal of children in the Australian and Swedish curriculum documents as active agents of learning in relation to the environment rather than active political agents of change in relation to sustainability practices. In this study, the authors propose the need for a more critical lens in developing children's agency and a greater focus on affirmative education for sustainability alongside transformative education for sustainability.

The Norwegian curriculum presents children as unique beings with their own needs who are able to express their views on matters affecting them (Table 1). The adults' role to rear children to actively participate in a democratic society is also highlighted. In the English framework, the child is described in a passive way: the child is "supported", must "listen attentively", "respond" and "follow instructions" (DfE 2017). Likewise, in the USA the child is viewed as a unique person who is able to succeed with "adults" help. The child is not perceived as an active citizen, and rather more emphasis is made on how the child is influenced by the environment rather than how they can influence the environment (Office of Head Start 2015).

Here, the authors argue that recognising children's agency at the individual and school level is not sufficient. Children have to be considered as political, environmental, social and economic agents who are able to act and contribute towards sustainability endeavours. Hence, curriculum documents should portray the child not only as a capable, competent and inquiring child but also a child with political agency who is able to alter the world through participation as an active and fully fledged citizen with a great deal to invest in their future. The authors also suggest that curriculum documents should not just recognise children's agency, but rather should indicate how their agency can be enacted. As indicated by Biesta and Tedder (2007), how children achieve agency is more important than just recognising their possession of it.

Moreover, drawing on contemporary post-human thinking, authors problematise the notion of agency and argue that agency is not just a human (conscious and intentional) attribute but rather a relational matter that collectively emerges within the relationship between human and more-than-human others-land/place, animals 
and materials. We argue that inter-relational agency Ritchie (2014) and distributed agency Latour (2005) offer different perspectives in understanding and addressing sustainability issues. Yet, how to embrace and manifest such relational, entangled and distributed agency within curricula remains another important area of inquiry.

\section{Human-Environment Relationships}

The five frameworks portray the human-environment relationship in more or less similar ways. As one of its learning and development goals, the Swedish curriculum highlighted "the need to develop children's interest and understanding of the different cycles in nature, the interconnection among people, nature and society and the need to 'conserve and care' for nature" (Skolverket 2016, p. 10). Similarly, the Norwegian framework stated that "Sustainable development ....is a prerequisite to take care of the life on earth as we know it", and children shall "learn to take care of their own, each other and nature" (Ministry of Education and Research 2017, p. 10). Likewise, while highlighting children's sense of belonging, the Australian curriculum pointed out children's "interdependence with others" and the need to encourage children to "explore relationships with other living and non-living things and observe, notice and respond to change" (DEEWR 2009, p. 29). On the other hand, the English curriculum indicated the need for children "to make sense of the physical world", and the USA curriculum indicated the need for "children's experience in nature" (Table 1).

Although three of the five frameworks (Sweden, Norway and Australia) mention human-environment interconnections, they appear to fall short of recognising the reciprocity of the relationship that acknowledges the agency of the environment and our inherited relationship with it (Ritchie 2013). The way the frameworks set the learning goals and guide activities appear to be anthropocentric and mainly rely on human agency, and human exceptionalism (McKenzie and Bieler 2016). However, the Australian curriculum has a strong emphasis on human's intertwined relationship with the environment, living and non-living things.

A prevailing commonality observed across most of the curricula was the tendency to consider the environment as a backdrop or a substrate for humans/ children to act upon: to be loved, to care for, to save, to conserve, to steward, to sympathise for, to respect, to experience and to appreciate. Although there is nothing inherently wrong with these approaches, the notion of environmental stewardship, a dominant discourse in environmental education, appears to present the human as a saviour of the environment and present the environment as a backdrop awaiting to be cared for and tamed by humans, and hence, it does not capture the complexity, entanglement and reciprocity of the relationship (Taylor 2017). It could well be that such anthropocentric human-environment relationships are a contributing factor in today's widely acknowledged Anthropocene era (i.e. a geological age that denote human impact on climate and the environment), which requires a rethinking of human-nature partnership/nature-culture binary in the Western context (Gibson et al. 2015).

Drawing on post-humanism and new materialism perspectives, some early childhood education scholars (Malone et al. 2017; Taylor 2013, 2017) have called 
for the human-environment entanglement and challenged the anthropocentric and often romanticised notions of children's nature experiences in the dominant Western-centric thinking within the environmental and sustainability education discourse. Particularly, a common world pedagogy (Taylor 2013) that attunes to children's relations with the more-than-human others in their local common world, should be considered within ECEfS where humans and more-than-humans (e.g. environment, land/place, animals, plants and materials) are considered within an assemblage.

Policy documents such as curriculum frameworks play an integral role here by portraying the inevitable intertwining of human and the environment, and the nature-culture entanglement which can set the tone for adjusting pedagogy and every day early childhood education practices accordingly. Curriculum documents should instead be able to portray the "messy" interconnection of children/ childhoods and the environment/the world in which they play out. This helps in designing a pedagogy that goes beyond the developmental, autonomous and learning child who is always expected and made to learn about and care for the environment, and instead shift to a pedagogy that aims for children and their inevitable entanglement with the more-than-human world and recognise that humans are not the only worthy contributors to and makers of the world.

\section{Philosophical and Theoretical Underpinnings}

Given the complex and contested concept of sustainability, it is no surprise that there is no agreement about which theoretical assumptions can best inform and guide sustainability-oriented pedagogies (Somerville and Williams 2015). This controversy has added an impetus and provoked scholars to challenge traditional early years' learning models and indicates the need for new forms of learning and understanding the world differently, which opens up alternative ways of knowing and dealing with sustainability challenges (Ärlemalm-Hagser and Davis 2014; Gibson et al. 2015; Malone et al. 2017). In particular, Davis (2014, p. 33) suggests the need to "rethink the socio-constructivist frameworks that underpin early childhood education internationally" which would lead to a "shift to critical, transformative early education". Her suggestion of an eco-sociocultural approach is based on the premise that any change to "programmes and pedagogies" should "support sustainable societies" by engaging with critical theory, often postulated as essential to support critical and reflective pedagogy (2014, p. 33).

As indicated in Table 1, the five curricula are predominantly based on childcentred sociocultural, social constructivist and Piagetian developmentalism learning theories, relating children's learning to activities, experiences and situations, and interactions with their physical environments (Lave and Wenger 1991; Piaget 1997, Vygotsky 1986). These dominant theoretical orientations emphasise children's social worlds, cognitive processes and human interactions. They tend to give centrality to the human autonomous child. The agency of non-humans and their relations with the child are not well considered. Although recognising children's agency is a vital necessity, such theoretical orientations might unwillingly/ 
unintentionally leave humans to remain in the habitual anthropocentric ways of learning and looking at the world and hence reinforce anthropocentrism.

This scenario urges us to question and reflect on the extent to which the dominant anthropocentric perspectives are helpful in engaging children in sustainability issues. As a result, authors question if there is a need to know sustainability differently (e.g. affectively and bodily) and create an alternative sustainability ethos, which brings about the need to seek and explore theories that can help to utilise the potential that lies beyond the human, the cognitive and the social world. In this study, post-humanism and new materialism were revealed as missing perspectives in ECEfS, essentially making it difficult for children to see that their (human) world and the more-than-human world are inevitably entangled and interconnected.

As an effort to counteract anthropocentric approaches, authors suggest ECEfS to consider post-humanism and new materialism theories (Somerville 2016; Taylor 2017). These theories allow us to see the world beyond the human child and lean towards a more inclusive, holistic, unified and ultimately "sustainable" world in which humans are not exceptional beings, but one part of the larger assemblage who co-inhabit the planet together with more-than-human others. Due to the relatively open nature of early years curriculum, we argue that early childhood is a wellsituated field for re-ontologising our world view and understanding of knowledge towards addressing sustainability beyond anthropocentric limitations. Hence, we assert that a thorough and extensive investigation of the theoretical and philosophical underpinnings of curricula would lead to deeper understanding and different constructs of sustainability itself.

\section{The Way Forward}

This article highlights the differences and similarities among the five national early childhood curricula frameworks. The authors used a continuum-based approach to summarise the findings. It should be noted that positioning the countries along continua is by no means precise, but rather a way to better understand the position of each national curriculum on the four aspects examined in this paper.

With respect to the presence of sustainability, the frameworks from Australia, Norway and somehow Sweden contained more explicit sustainability language, whereas the languages from England and USA were implicit. Regarding views of the child, Sweden's framework came closest to positioning the child as a world citizen. Australia and Norway, located in the middle of the continuum, viewed the child as an active and agentic individual. England and the USA viewed the child in a more passive manner. As for human-environmental relationship, the framework from Australia expressed reciprocity and entanglement which is proposed as being related to the need to acknowledge indigenous practices. The other frameworks, especially England and USA, were more anthropocentric. Regarding philosophical/ theoretical underpinnings, all five frameworks embodied a sociocultural, human development approach to curricula (Fig. 1).

To conclude, curriculum frameworks play an integral role in offering early childhood practitioners the guidance and support to develop their knowledge and 


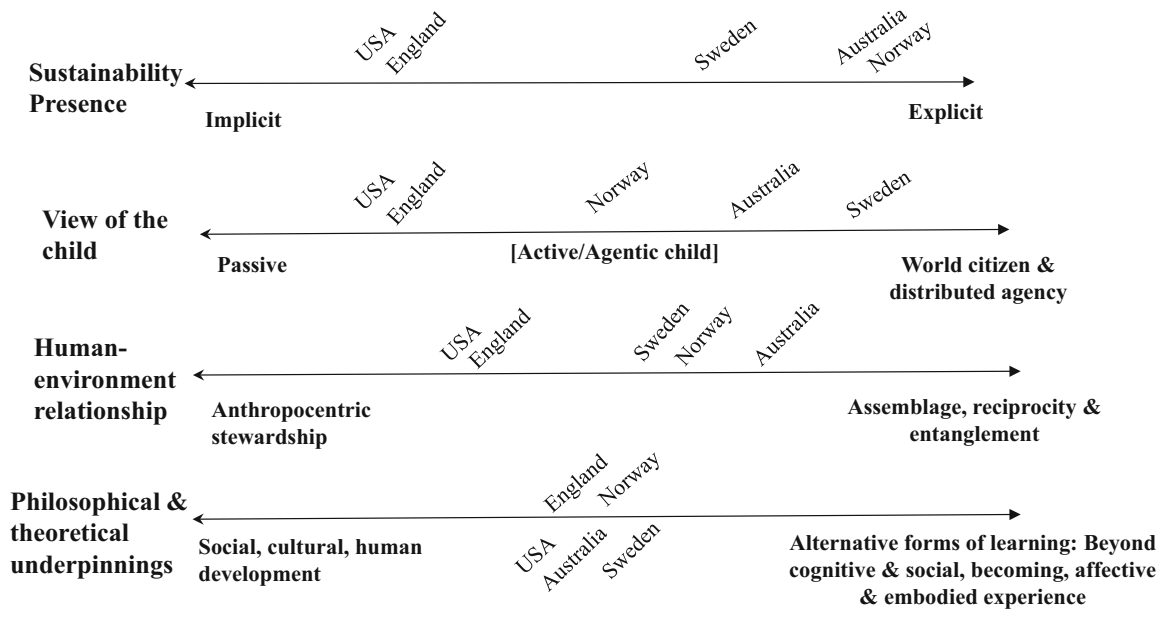

Fig. 1 Positioning of countries on continua representing the four content themes explored in the analyses for five national early childhood curricular frameworks

understanding of issues related to sustainability. To this effect, a robust representation and integration of sustainability within the curriculum is necessary. Based on the discussion and analysis of the curricula and bearing in mind the different sociopolitical contexts in which each national curriculum framework has been developed, a deeper understanding of the limitations and possibilities for reorienting early years' curricula towards sustainability has been presented.

As a provocation for further study, we ask: "What might an early childhood education curriculum, that manifest explicit language of sustainability, views children as world citizens and portrays a unified world view with entangled human and more-than-human others, look like?"

Since all the curricula contexts addressed in this contribution are "Western", authors suggest that an investigation of sustainability and its associated concepts within early years' frameworks from non-Western nations is required in order to understand their cultural and political contexts. Such an investigation would pave the way for a more global path of understanding of sustainability in ECEfS. Particularly, transnational collaborative studies that resonate with the recently launched United Nations agenda, Transforming Our World: the 2030 Agenda for Sustainable Development (UN 2015), are important. The Agenda 2030 declares that global partnerships are essential in moving our world towards a global "sustainable" path. Hence, comparative endeavours among nations foster better understandings of how sustainability is expressed in a culturally relevant and localised manner and global understanding of the principles and curricular guidance required.

Acknowledgements We are grateful for the enormous contribution by Donna Berthelsen (IJEC editor) and guest editors Sue Elliot and Eva Arlemalm-Hagser. We are also thankful to Hannah Wesselby and Felix Kwabena Donkor for translating the abstract into French and Spanish. 
Open Access This article is distributed under the terms of the Creative Commons Attribution 4.0 International License (http://creativecommons.org/licenses/by/4.0/), which permits unrestricted use, distribution, and reproduction in any medium, provided you give appropriate credit to the original author(s) and the source, provide a link to the Creative Commons license, and indicate if changes were made.

\section{References}

Alvestad, M., \& Samuelsson, I. P. (1999). A comparison of the national preschool curricula in Norway and Sweden. Early Childhood Research and Practice, 1(2), 1-21.

Ärlemalm-Hagsér, E., \& Davis, J. (2014). Examining the rhetoric: a comparison of how sustainability and young children's participation and agency are framed in Australian and Swedish early childhood education curricula. Contemporary Issues in Early Childhood, 15(3), 231-244.

Barad, K. (2007). Meeting the universe halfway: Quantum physics and the entanglement of matter and meaning. Durham: Duke University Press.

Barratt Hacking, E., Barratt, R., \& Scott, W. (2007). Engaging children: Research issues around participation and environmental learning. Environmental Education Research, 13(4), 529-544.

Battersby, M., \& Bailin, S. (2011). Critical inquiry: Considering the context. Argumentation, 25(2), 243-253.

Berthelsen, D., \& Brownlee, J. (2005). Respecting children's agency for learning and rights to participation in child care programs. International Journal of Early Childhood, 37(3), 49-60.

Biesta, G., \& Tedder, M. (2007). Agency and learning in the life course: Towards an ecological perspective. Studies in the Education of Adults, 39(2), 132-149.

Boylan, M. (2009). Critical inquiry: The process of argument. Boulder, CO: Westview Press.

Bray, J. N., Lee, J., Smith, L., \& Yorks, L. (2000). Collaborative inquiry in practice: Action, reflection and making meaning. London: SAGE.

Centre for Environment and Sustainability (GMV). (2009). Gothenburg recommendations on education for sustainable development. Göteborg, Sweden: Chalmers University of Technology/University of Gothenburg. Retrieved from www.chalmers.se/gmv.

Corcoran, P. B., \& Osano, P. M. (2009). Young people, education, and sustainable development: Exploring principles, perspectives, and praxis. Wageningen: Wageningen Academic Publishers.

Davis, J. (2009). Revealing the research 'hole' of early childhood education for sustainability: A preliminary survey of the literature. Environmental Education Research, 15(2), 227-241.

Davis, J. M. (2014). Examining early childhood education through the lens of education for sustainability: Revisioning rights. In J. Davis \& S. Elliott (Eds.), Research in early childhood education for sustainability: International perspectives and provocations (pp. 21-37). London: Routledge.

Davis, J. (2015). Young children and the environment: Early education for sustainability. Melbourne: Cambridge University Press.

Davis, J., \& Elliott, S. (Eds.). (2014). Research in early childhood education for sustainability: International perspectives and provocations. New York: Routledge.

DEEWR. (2009). Belonging being and becoming: The early years learning framework. Canberra ACT: Department of Education Employment and Workplace Relations. Retrieved from http://education. gov.au/earlyyears-learning-framework.

Department for Education. (2017). Statutory framework for the early years foundation stage: Setting the standards for learning, development and care for children from birth to five. Runcorn: Department for Education.

Elliott, S., \& McCrea, N. (2015). Gaps and challenges informing professional learning about early childhood education for sustainability. The Social Educator, 33(3), 17-28.

Gibson, K., Rose, D. B., \& Fincher, R. (Eds.). (2015). Manifesto for living in the anthropocene. Brooklyn, NY: Punctum.

Guest, G., Namey, E. E., \& Mitchell, M. L. (2012). Collecting qualitative data: A field manual for applied research. Los Angeles, CA: SAGE.

Haraway, D. J. (2008). When species meet. Minnesota: University of Minnesota Press.

Hedefalk, M., Almqvist, J., \& Östman, L. (2014). Education for sustainable development in early childhood education: A review of the research literature. Environmental Education, 21(7), 975-990. 
Hill, L. T., Stremmel, A. J., \& Fu, V. R. (2005). Teaching as inquiry, rethinking curriculum in early childhood education. London: Pearson Education.

Knight, S. (Ed.). (2013). International perspectives on forest school: natural spaces to play and learn. London: SAGE Publications.

Latour, B. (2005). Reassembling the social: An introduction to actor network theory. Oxford: Oxford University Press.

Lave, J., \& Wenger, E. (1991). Situated learning: Legitimate peripheral participation. Cambridge: Cambridge University Press.

Malone, K. (2004). "Holding environments": Creating spaces to support children's environmental learning in the 21st century. Australian journal of environmental education, 20(02), 53-66.

Malone, K., et al. (2017). Reimagining sustainability in precarious times. London: Springer.

McKenzie, M., \& Bieler, A. (2016). Critical education and sociomaterial practice: Narration, space and the social. Bern: Peter Lang Press.

Ministry of Education and Research. (2010). Förskola i utveckling-bakgrund till ändringar i förskolans läroplan. Stockholm: Ministry of Education and Science.

Ministry of Education and Research. (2017). Rammeplan for barnehagen (Framework plan for the kindergarten). Oslo: Norwegian Directorate for Education and Training.

Office of Head Start. (2015). Head start early learning outcomes framework: Ages birth to five. Washington, DC: U.S. Department of Health and Human Services, Administration of Children and Families.

Piaget, J. (1997). Development and learning. In M. Gauvain \& M. Cole (Eds.), Readings of the development of children (pp. 19-28). New York: W.H. Freeman and Company.

Pramling Samuelsson, I., \& Kaga, Y. (2008). The contribution of early childhood education to a sustainable society (pp. 73-80). Paris: UNESCO.

Ritchie, J. (2013). Sustainability and relationality within early childhood care and education settings in Aotearoa New Zealand. International Journal of Early Childhood, 45(3), 307-326.

Ritchie, J. (2014). Learning from the wisdom of elders. In J. Davis \& S. Elliot (Eds.), Research in early childhood education for sustainability: International perspectives and provocations (pp. 49-60). Abingdon, OX: Routledge.

Sageidet, B. M. (2014). Norwegian perspectives on ECEFS. In J. Davis \& S. Elliott (Eds.), Research in early childhood education for sustainability (pp. 112-124). London: Routledge.

Schein, D. (2014). Nature's role in children's spiritual development. Children Youth and Environments, 24(2), 78-101.

Silverman, D. (2011). Interpreting qualitative data (4th ed.). London: SAGE.

Skolverket, (2016). Curriculum for the preschool Lpfö 98 revised 2010 [Läroplan för förskolan]. Stockholm: Skolverket.

Smith, A. B. (2007). Children's rights and early childhood education. Australian Journal of Early Childhood, 32(3), 1-8.

Sobel, D. (2015). Nature preschools and forest kindergartens: The handbook for outdoor learning. St. Paul, MN: Redleaf Press.

Somerville, M. (2016). The post-human I: encountering 'data' in new materialism. International Journal of Qualitative Studies in Education, 29(9), 1161-1172.

Somerville, M., \& Williams, C. (2015). Sustainability education in early childhood: An updated review of research in the field. Contemporary Issues in Early Childhood, 16(2), 102-117.

Taylor, A. (2013). Reconfiguring the natures of childhood. London: Routledge.

Taylor, A. (2017). Beyond stewardship: Common world pedagogies for the Anthropocene. Environmental Education Research, 23, 1-14.

UNESCO. (2005). UN decade of education for sustainable development. Paris: UNESCO. Retrieved from http://unesdoc.unesco.org/images/0014/001416/141629e.pdf.

United Nations (UN). (2015). Transforming our world: The 2030 Agenda for sustainable development. New York: United Nations.

Utbildningsdepartementet. (2017). Assignment for a revision of the curriculum for preschool (2017-0420). Retrieved from http://www.regeringen.se/regeringsuppdrag/2017/04/uppdrag-om-en-oversynav-laroplanen-for-forskolan/.

Vandenbroeck, M., \& Bie, M. B. D. (2006). Children's agency and educational norms: A tensed negotiation. Childhood, 13(1), 127-143.

Vygotsky, L. S. (1986). Thought and language. Cambridge, MA: Harvard University Press. 